\title{
The most northern museum in the world
}

Reconstruction and museumification of the Soviet Polar Station

"Tikhaya Bay" on the Franz Joseph land

\section{Pavel Filin}

\section{Q OpenEdition \\ 1 Journals}

\section{Electronic version}

URL: https://journals.openedition.org/artefact/10278

DOI: $10.4000 /$ artefact. 10278

ISSN: 2606-9245

Publisher:

Association Artefact. Techniques histoire et sciences humaines, Presses universitaires du Midi

\section{Printed version}

Date of publication: 7 October 2021

Number of pages: $317-318$

ISBN: 978-2-8107-0755-3

ISSN: 2273-0753

\section{Electronic reference}

Pavel Filin, "The most northern museum in the world", Artefact [Online], 14 | 2021, Online since 07 October 2021, connection on 07 October 2021. URL: http://journals.openedition.org/artefact/10278; DOI: https://doi.org/10.4000/artefact.10278

\section{(c) (i) (9)}

Artefact, Techniques, histoire et sciences humaines est mise à disposition selon les termes de la Licence Creative Commons Attribution - Pas d'Utilisation Commerciale - Pas de Modification 4.0 International. 


\section{Encadré}

\section{The most northern museum in the world}

\section{Reconstruction and museumification of the Soviet Polar Station "Tikhaya Bay" on the Franz Joseph land}

\section{Pavel Filin}

T n 2009, the Government of the Russian Federation established the Russian Arctic National Park in the northern part of the Novaya Zemlya archipelago.

1 In 2016, its territory expanded considerably, practically the entire territory of Franz Josef Land was included ${ }^{1}$. Bukhta Tikhaya (Tikhaya Bay, "Calm Bay " in English) on Hooker Island, one of the first and very well-preserved polar stations in the Arctic, became the main stronghold of the National Park on Franz Josef Land (Fig. 1). Almost all ships that come to the high latitude of Russian Arctic visit Bukhta Tikhaya. The polar station was organized in 1929 under the leadership of Otto Yulyevich Schmidt, a prominent Soviet academician. The station represents a very well-preserved complex of structures of the 1920s-1950s, associated with the history of development of the high latitude Arctic and the North Pole, namely a hangar for seaplanes, a weather station, a wooden garage for equipment, a wind farm, residential buildings, a post-office, small warehouses, etc. The most significant structure is a hangar for seaplanes $\left(255 \mathrm{~m}^{2}\right)$ (Fig. 2).

In June 2017, an agreement was signed between the Russian Arctic National Park and the NGO «Arctic Museum and Exhibition Center ». The document allowed the establishment of a museum-guest center in a hangar for seaplanes. Eventually, it was planned to create the northernmost museum of the Arctic, where one can meet the history of the Franz Josef Land, the Arctic and the North Pole. The Russian Arctic National Park, in cooperation with the Arctic Museum and

1. Expansion of the territory of the Russian Arctic National Park. Resolution of the Government of the Russian Federation dated August 25 ${ }^{\text {th }}$, 2016, n 840 // http://government.ru/dep_news/24307/ 
Exhibition Center, is developing a long-term program for the gradual restoration of the station in order to create an open-air museum and manage the cultural heritage of the station by its $100^{\text {th }}$ anniversary in 2029 .

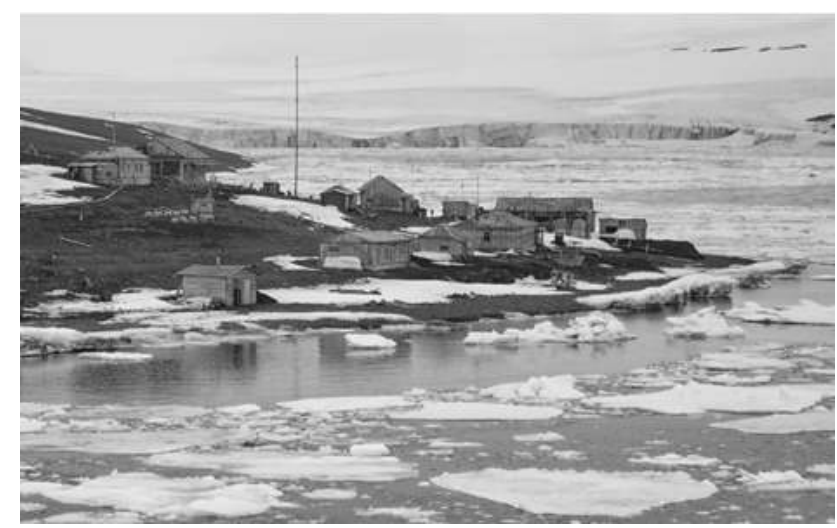

\section{Fig. 1. - “Bukhta Tikhaya” station}

\section{Photograph by Pavel Filin}

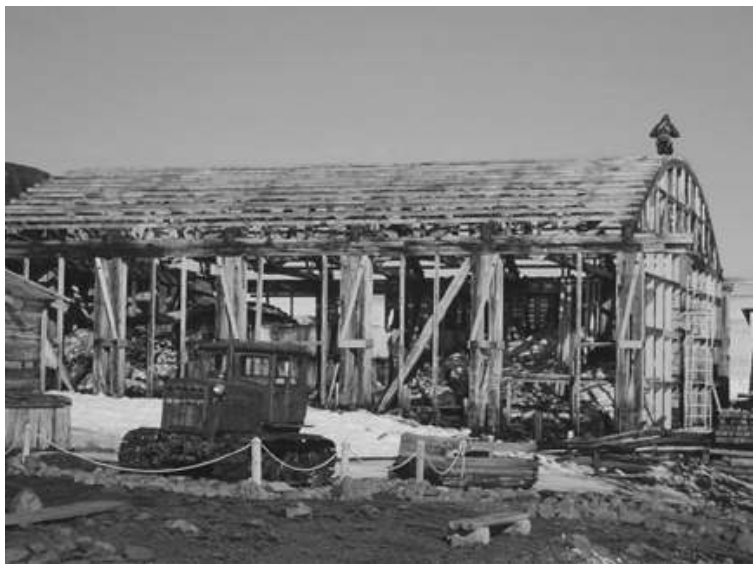

Fig. 2. - The hangar at the end of the 2018 season. Restoration works in progress

Photograph by Pavel Filin

Pavel Anatolievich Filin is a leading expert and practitioner in the preservation and management of the Russian maritime heritage. After seven year as deputy director of the Icebreaker Krassin Museum he was appointed as director of the Museum and Exhibition Center for Technical and Technological Development of the Arctic. His major area of expertise is the development of sustainable heritage tourism in the Russian part of the Arctic. Contact: arcticmuseum@mail.ru 